\title{
Genotoxic and Cytotoxic Damage by Cyclophosphamide and Adriamycin as a Response to Treatment in Breast Cancer Patients: Pilot Study
}

\author{
Jimena Garibay-Garcia1, Fernando Mejia-Sanchez ${ }^{1}$, Eduardo Ramírez-San-Juan², \\ Miriam V. Flores-Merino' ${ }^{1}$, Julieta Castillo-Cadena ${ }^{1}$ \\ ${ }^{1}$ Research Center in Medical Science, Autonomous University of the State of Mexico, Toluca, Mexico \\ ${ }^{2}$ National School in Biological Science, Instituto Politécnico Nacional, Mexico City, Mexico \\ Email: jcastillo cadena@hotmail.com
}

Received 6 January 2015; accepted 4 February 2015; published 5 February 2015

Copyright (C) 2015 by authors and Scientific Research Publishing Inc.

This work is licensed under the Creative Commons Attribution International License (CC BY).

http://creativecommons.org/licenses/by/4.0/

(c) (i) Open Access

\section{Abstract}

The aim of this study was to evaluate the genotoxicity induced by cyclophosphamide-adriamycin treatment in breast cancer patients through the frequencies of Sister Chromatid Exchange (SCE), Replication Index (RI), Mitotic Index (MI) and Cell Proliferation Index (CPI) and to study the possible association between biomarkers of genotoxicity and the early response to treatment. The frequencies were obtained before and immediately after therapy from 17 patients with breast cancer $(p<0.001)$. Response to treatment was assessed after two years resulting in 12 patients in a state of remission. MI and CPI had high values after treatment in women with active cancers compared to those in a state of remission, however there were not significant differences. Conclusions: It is possible that MI y CPI biomarkers can serve as indicators for early assessment of treatment with cyclophosphamide-adriamycin. It should be noted that these are preliminary results and further study is necessary.

\section{Keywords}

Sister Chromatid Exchange, Genotoxicity Biomarkers, Breast Cancer, Cyclophosphamide, Adriamycin

\section{Introduction}

Breast cancer is a serious threat for women's health; more than 10 million women are diagnosed each year in the

How to cite this paper: Garibay-Garcia, J., et al. (2015) Genotoxic and Cytotoxic Damage by Cyclophosphamide and Adriamycin as a Response to Treatment in Breast Cancer Patients: Pilot Study. Journal of Cancer Therapy, 6, 163-168. 
world with this malignancy. In Mexico, with a population of over 100 million, between 2 and 4 women per 100,000 die from breast cancer; an increment of 16,500 new cases are estimated for 2020 [1] [2]. Therapy with cyclophosphamide and adriamycin as chemotherapeutic agents is one of the most widely used to treat breast cancer. These drugs exert their effect by disrupting DNA, which leads to cell death, resulting in the control of the disease and on the other hand, in a lot of secondary effects [3] [4]. Cyclophosphamide is an antineoplastic drug with immunosuppressive properties. It belongs to the family of the alkylating agents and it is considered one of the most potent drugs ever synthesized. It needs to be activated by the hepatic microsomal enzyme system in order to be cytotoxic. During that metabolic activation, involving the alkyl and nucleophilic sites of DNA, adducts are formed [5]. Alkylation products are important in the biological effects caused by this and other alkylating agents. It is a strong bone marrow depressant, which is its biggest toxic effect: it leads to a dose related suppression of myelopoiesis, directly attacking the bone marrow. Lymphoid proliferative cells are destroyed, but some resting cells can also be attacked [6]. Adriamycin, also called doxorubicin, belongs to the anthracycline family. These drugs are among the more used cytotoxic drugs against cancer and it has become the main treatment of breast cancer [6] [7]. The adverse effects include: bone marrow depression, related cardiac toxicity, which increases with the dose accumulation and severe or total alopecia at standard dose [6].

On the other hand, it has been shown that cyclophosphamide is an excellent inducer of Sister Chromatid Exchanges (SCE), which is a sensitive biomarker for detecting the mutagenic and oncogenic potentiality of various agents [8]. It has also been reported that the Mitotic Index (MI) and Replication Index (RI), together with other biological markers as Cell Proliferation Index (CPI) are suitable indicators of cell proliferation, especially in genotoxicity studies, because of their sensitivity to determine the cytotoxic and cytostatic action of various environmental pollutants and therapeutic agents [9] [10].

For the evaluation of response to this treatment, a clinical assessment is performed after two to three cycles, using the system of the World Health Organization (WHO) or the RECIST system [11]. Nowadays, it is impossible to know whether the therapy will be completely effective for the patient after the first application, the evaluation is made usually when half of the treatment has been administrated, usually after a period of 4 to 5 months. At this point patients not responding to the treatment will be detected, along with patients in whom the toxicity was too high to continue the scheme. Jones et al. [12] studied a group of 55 women with breast cancer treated with adriamycin-cyclophosphamide, it was found that $83 \%$ had a favorable response to treatment, while the rest did not show an overall improvement after four cycles. Finally, this study aimed to determine the genotoxicity induced by adriamycin-cyclophosphamide and the possible association between the frequencies of SCE, RI, MI and CPI and the early response to treatment in breast cancer patients.

\section{Materials and Methods}

\subsection{Studied Group}

The patient group was formed by 17 women with breast cancer (mean age 47 years) from the chemotherapy service of the ISSEMyM State Oncology Center (Toluca, México). The study excluded patients who had had previous cancer treatment. Written informed consent was obtained from each participant according to the official Mexican regulations in the field of health research [13]. The authors certify that the study was approved by the Bioethics Committee of the ISSEMyM State Oncology Center and that all experiments were done under full compliance with all government policies and the Helsinki Declaration [14].

\subsection{Chemotherapy}

Patients were treated with adriamycin $\left(60 \mathrm{mg} / \mathrm{m}^{2}\right)$ and cyclophosphamide $\left(600 \mathrm{mg} / \mathrm{m}^{2}\right)$ on Day 21 of the cycle. The scheme was repeated during 8 cycles in patients under adjuvant chemotherapy and 4 cycles for those under neoadjuvant chemotherapy.

\subsection{Blood Sample}

Two blood samples were taken by venous puncture in the arm, in a heparinized vacutainer tube from each patient. The first sample $(3 \mathrm{~mL})$ was taken right before starting the therapy, to determine the basal rate. Subsequently, the second sample of $7 \mathrm{~mL}$ was obtained 5 minutes after the end of the first dose. All samples were stored at room temperature until the time of the test. 


\subsection{Lymphocyte Culture}

The lymphocyte culture medium consisted of $5 \mathrm{~mL}$ of RPMI-1640 (Sigma, USA), $0.25 \mathrm{~mL}$ of phytohemaglutinin (Sigma, USA), $0.4 \mathrm{~mL}$ of penicillin-streptomycin antibiotic (Microlab, Mexico) and $0.25 \mathrm{~mL}$ of BrdU (bromodeoxyuridine (10 $\mathrm{\mu g} / \mathrm{mL}$; Sigma, USA). Whole blood (12 to 18 drops) was added to the culture medium and incubated for 72 hours at $37^{\circ} \mathrm{C} \pm 1^{\circ} \mathrm{C}$ in $5 \% \mathrm{CO}_{2}$ atmosphere.

\subsection{Determination of Biomarkers before Treatment}

After 72 hours, $0.3 \mathrm{~mL}$ of colchicine $(10 \mu \mathrm{g} / \mathrm{mL}$; Sigma, USA) was added to the culture flask and incubated for 1 hour. The rest of the harvest was performed using the Moorhead method [15]. Finally, the slides were stained according to the modified technique of Perry \& Wolf [16], and coded for blind analysis.

\subsection{Determination of Biomarkers after Treatment}

Considering that a high cell death occurs because of the treatment, we added 24 hours at the very beginning of the incubation, in order to obtain an acceptable cell number to examine SCE, RI, MI and CPI. After these 24 incubating hours, $0.25 \mathrm{~mL}$ of $\mathrm{BrdU}(10 \mu \mathrm{g} / \mathrm{mL})$ was added to the lymphocyte culture, the incubation continued for 72 more hours (the total time of culture was 96 hours). Harvest of cells was then performed by adding $0.3 \mathrm{~mL}$ of colchicine to the culture flask (Sigma, USA, $10 \mu \mathrm{g} / \mathrm{mL}$ ) and incubated for 3.5 hours $\left(37^{\circ} \mathrm{C}, 5 \% \mathrm{CO}_{2}\right.$ ).

\subsection{Analysis of Biomarkers}

For SCE, 30 metaphases in the second cycle of replication were analyzed. Terminal SCEs were counted as an event and intercalary ones as two. For RI, 100 consecutive metaphases were counted by separating the first, second and third cycle of replication. The formula proposed by Krishna [17] was applied: RI = [1(M1) + 2(M2) + 3(M3)]/100, where M1, M2 and M3 represent the number of metaphases in the first, second and third replication cycles respectively. For MI, the number of metaphase cells found in 2000 successive nuclei was evaluated with the following formula: MI $=$ (number of metaphases $\times 100$ )/2000 transformed nuclei. For CPI, 2000 nuclei were counted by identifying transformed, necrotic and apoptotic nuclei, according to Fennec [18], and the following formula was applied: CPI $=($ transformed $\times 100$ nuclei $) /$ nuclei counted.

\subsection{Statistical Analysis}

The data was analyzed with the Shapiro-Wilk test. Paired t-Test was applied to SCE, CPI and Wilcoxon test to RI and MI and the treatment response was analyzed by Mann-Whitney U test. The statistical program Sigma Plot for Windows (Version 11.0, Systat Software, Inc.) was used.

\section{Results}

Samples were collected from 17 breast cancer patients, whose average age was 47 years in a range of 37 - 61 years, they had the disease in Stages IIA (23.5\%), IIB (29.4\%), IIIA (17.7\%), IIIB (17.6\%) and two cases were non classifiable (11.8\%). For SCE, there was an average of $0.64 \pm 0.25$ SCE/cell in a range of 0.37 to 1.23 before chemotherapy (bQT); and an average of $1.63 \pm 0.90 \mathrm{SCE} /$ cell in a range of 0.57 to 3.4 after chemotherapy $(\mathrm{aQT})$. Paired t-Test showed significant difference $(\mathrm{p}=0.001)$ between before and after treatment, all these results are shown in Table 1 . The analysis of the values of each of the cases showed that $47 \%$ of patients exhibited a dramatic increase in SCE bQT (more than 200\%) compared with the values of aQT.

For the CPI there was an average value of $63.6 \pm 17.7$ in the range of 30.4 to $99.9 \mathrm{bQT}$ and $28.3 \pm 23.8$ in the range of 4.5 to $89.2 \mathrm{aQT}$. According to the paired t-Test, there were statistically significant differences ( $<$ 0.001 ; Table 1) between the values aQt and bQT. Moreover, it was found that approximately $29 \%(n=5)$ of the cases presented a markedly decrease in the CPI, 6 times less than the value before treatment (63.3 bQT versus $10.8 \mathrm{aQT})$.

For RI, there was a decrease of bQT versus aQT results, a median of 1.46 in a range of 1.16 to 1.61 against a median of 1.15 in a range of 0.15 to 1.44 respectively. The Wilcoxon test showed a significant difference ( $\mathrm{p}<$ 0.001), all this results are shown in Table 2. The analysis per individual demonstrated that $11.7 \%$ of the cases presented a decrease in RI (1.42 in the values of bQT versus $0.22 \mathrm{aQT}$ ). In the case of MI, it was obtained a 
Table 1. Biomarker results of SCE and CPI values in blood lymphocytes before and after treatment.

\begin{tabular}{ccc}
\hline Biomarker & Mean Value bQT $( \pm$ SD $)$ & Mean Value aQT $( \pm$ SD $)$ \\
SCE & ${ }^{a} 0.64 \pm 0.25$ & $1.63 \pm 0.90$ \\
CPI & ${ }^{a} 63.6 \pm 17.7$ & $28.3 \pm 23.8$ \\
\hline
\end{tabular}

${ }^{\mathrm{a}}$ Paired t-Test for SCE and CPI before vs after chemotherapy, $\mathrm{p}<0.001$.

Table 2. Biomarker results of RI and MI values in blood lymphocytes before and after treatment.

\begin{tabular}{ccc}
\hline Biomarker & Median bQT & Median aQT \\
\hline RI & $1.46^{\mathrm{a}}$ & 1.15 \\
MI & $1.3^{\mathrm{a}}$ & 0.38 \\
\hline
\end{tabular}

${ }^{\mathrm{a}}$ Wilcoxon test for RI and MI before versus after chemotherapy, $\mathrm{p}<0.001$.

median of 1.3 bQT with a range from $0.15 \%$ to $16.6 \%$ and a median of 0.38 aQT with an interval of $0.05 \%$ to $16.2 \%$. Wilcoxon test showed that the decrease was significant $(\mathrm{p}<0.001)$; these results are show in Table 2. The analysis of MI per individual showed that $34.8 \%$ of the cases presented a decrease, 2.1 in the values of bQT versus $0.19 \mathrm{aQT}$. Analysis of data from all selected biomarkers showed significant difference in all patients when comparing baseline data (bQT) with those values obtained after the first dose of treatment.

In order to find out if any of the biomarkers may be an indicator of early response to treatment, the clinical status of all patients after completion of 8 treatment cycles was documented by reviewing their records. On this basis, those patients who reported an active state of the neoplasm and those in remission were grouped; four patients showed an active state and twelve a state of remission, the difference was not statistically significant (MannWhitney $U$ test) between patients with neoplasm $(n=4)$ compared with patients in remission $(n=12)$. Detailed data is presented in Table 3 .

\section{Discussion}

Human lymphocytes and cell lines have been used as systems for the estimation of genotoxic damage by different agents or drugs [19]. Breast cancer is a common disease in mature women. In this study the average age of the patients was 47 years, which agrees with other authors such as Knaul et al. [2], who reported that $60 \%$ of women who die from this malignancy are between 30 and 59 years old, a heavy burden of early death.

Banerjee and Benedict [8] determined in vitro genotoxic damage using SCE in the A(T1) C1-3 hamster cell line exposed to antineoplastic agents such as Melphalan, Thiotepa, Actinomycin D, Bleomycin, Hycanthone and 5-aza-C, obtaining a significant increase in SCE. Ocampo et al. [20] performed the assessment of in vitro genotoxic damage induced by Basuco in human lymphocytes, achieving a significant increase in the value of SCE in exposed cells. Regarding SCE, in this study was observed an increase of its value after chemotherapy, indicating a damage caused by the drugs to the DNA of patients as reported before [9] [18]. The fact that in this study was observed a higher frequency of SCE means that drugs are causing mutations that can lead to cell death at the level of lymphocytes, which is most likely the reflection of what is happening at the level of cancer cells.

In regard to MI and CPI, it is known that neoplastic cells have high values for these two biomarkers. This is due to the disarray or loss of control in cell proliferation [21] [22]. Based on this, it is expected that cells exposed to agents or drugs with a cytotoxic and cytostatic effect will show a decrease in RI, MI and CPI. Hick et al. [23], in a group of 20 argentinians exposed to arsenic, found a significant decrease in MI and CPI compared with a control group. The results of that study are similar to ours, as the statistical analysis resulted in a significant decrease in RI, MI and CPI obtained before versus after the first treatment dose. The decrease in the values of RI, MI and CPI means that the cycle of cells that have been exposed to antineoplastic drugs is lengthening. This is because if there is DNA damage under ordinary conditions, the cell cycle must stop at a check point to repair the damage, which in this case was caused by chemotherapy, therefore lengthening the cycle to promote the repair of damaged DNA [9].

The treatment assessed in this study is one of the main therapies used for breast cancer. Adriamycin and cyclophosphamide are intended to cause damage to the genetic material of neoplastic cells and thereby inhibit their 
Table 3. Statistical analysis of SCE, RI, MI and CPI grouped according to treatment response.

\begin{tabular}{cccc}
\hline Biomarker & Active Neoplasm (Median aQT) $\mathrm{n}=4$ & Remission (Median aQT) $\mathrm{n}=12$ & $\mathrm{p}$ Value \\
\hline SCE & 1.30 & 1.66 & 1.0 \\
RI & 1.155 & 1.085 & 0.504 \\
MI & 0.34 & 1.45 & 0.584 \\
CPI & 17.63 & 28.64 & 0.303 \\
\hline
\end{tabular}

Mann-Whitney U test.

proliferation [12] [24]. In vivo studies for assessing the damage caused by treatment with certain drugs have been reported. Although these drugs had proven to be mutagenic, clastogenic and in general, genotoxic, in vitro tests are not currently performed in patients: personalized response is not evaluated because their effects depend on characteristics of each organism. In the present study, response to treatment was variable; most patients went into remission after completing the eight cycles of their treatment schedule. However, it was found that four patients had active neoplasms after two years of treatment, with CPI and MI behaving differently than in remission. That is, cytotoxicity and proliferation kinetics did not decrease after the first treatment, showing values above those found in patients in remission. These preliminary results invite to keep searching for biomarkers that may be indicative of early response to treatment.

In summary, treatment of breast cancer generally includes the application of 8 cycles of chemotherapy, adriamycin and cyclophosphamide being the most widely used scheme. Response to treatment is assessed after the third cycle, or at the end of it. The present study showed that there is an induction of SCE and a reduction in the frequency values of MI, RI and CPI after the first dose of adriamycin and cyclophosphamide. Therefore, these biomarkers have the possibility of being an early indicative of the treatment response. Moreover, this study showed that genotoxicity of adriamycin and cyclophosphamide can be induced and detected after the first cycle of treatment in breast cancer patients.

\section{Acknowledgements}

The authors express their gratitude to the patients who kindly agreed to participate in this study, to Dr. José Luis Barrera and Dr. Paula Cabrera from the ISSEMYM State Oncological Center. Project funded in part by the UAEMéx, agreement No. 3452/2013CHT.

\section{Disclosure Statement}

No competing financial interests exist.

\section{References}

[1] Mohar, A., Bargallo, E., Ramírez, M.T., Lara, F. and Beltrán-Ortega, A. (2009) Recursos disponibles para el tratamiento del cáncer de mama en México. Salud Pública de México, 51, 263-269. http://dx.doi.org/10.1590/S0036-36342009000800017

[2] Knaul, F.M., Nigenda, G., Lozano, R., Arreola-Ornelas, H., Langer, A. and Frenk, J. (2009) Cáncer de mama en México: Una prioridad apremiante. Salud Pública de México, 51, 335-344. http://dx.doi.org/10.1590/S0036-36342009000800026

[3] Bland, I.K. and Copeland, E.M. (2000) La mama, manejo multidisciplinario de las enfermedades benignas y malignas. Médica Panamericana, Buenos Aires.

[4] Khosravi-Shahi, P., Izarzugaza-Perón, Y., Encinas-García, E., Díaz-Muñoz-de-la-Espada, V.M. and Pérez Manga, G. (2008) Tratamiento adyuvante en el cáncer de mama operable. Anales de Medicina Interna, 25, 36-40. http://dx.doi.org/10.4321/S0212-71992008000100010

[5] Rodríguez-Reyes, R.G. (2000) Persistencia de las lesiones causadas al ADN por agentes alquilantes, involucradas en la producción de intercambios de cromátides hermanas. Revista Especializada en Ciencias de la Salud, 3, 3-13.

[6] Katzung, B.G. (1996) Farmacología Básica y Clínica. El Manual Moderno, México.

[7] Arce, C., Martínez-Tlahuel, J. and Lara, F.U. (2006) Quimioterapia adyuvante en cáncer de mama: Presente y futuro. 
Cancerología, 1, 177-185.

[8] Banerjee, A. and Benedict, W.F. (1979) Production of Sister Chromatid Exchanges by Various Cancer Chemotherapeutic Agents. Cancer Research, 39, 797-799.

[9] López-Nigro, M.M. and Carballo, M.A. (2008) Los nitroimidazoles como modelo de mutagénesis química y muerte celular. Theoria, 17, 47-62.

[10] Uribe-Alcocer, M. and Díaz-Jaimes, J.P. (2001) Fish Chromosomes as Biomarkers of Genotoxic Damage and Proposal for the Use of Tropical Catfish Species for Short-Term Screening of Genotoxic Agents. Environmental Science Research, 56, 361-390.

[11] Brugés, R., Guzmán, L.H., Sánchez, O., Díaz, S. and Vergara, E. (2009) Neoadyuvancia en cáncer de mama. Revista Colombiana de Cancerología, 13, 157-174. http://dx.doi.org/10.1016/S0123-9015(09)70134-9

[12] Jones, S.E., Durie, B.G.M. and Salmon, S.E. (1975) Combination Chemotherapy with Adriamycin and Cyclophosphamide for Advanced Breast Cancer. Cancer, 36, 90-97. http://dx.doi.org/10.1002/1097-0142(197507)36:1<90::AID-CNCR2820360104>3.0.CO;2-H

[13] SEGOB (2012) Norma oficial mexicana NOM-012-SSA3-2012, Que establece los criterios para la ejecución de proyectos de investigación para la salud en seres humanos. http://dof.gob.mx/nota_detalle.php?codigo=5284148\&fecha=04/01/2013

[14] WMA (2013) Helsinki Declaration. http://www.wma.net/es/30publications/10policies/b3/

[15] Moorhead, P.S., Nowell, P.C., Mellman, W.J., Battips, D.M. and Hungerford, D.A. (1960) Chromosome Preparations of Leukocytes Cultured from Human Peripheral Blood. Experimental Cell Research, 20, 613-616. http://dx.doi.org/10.1016/0014-4827(60)90138-5

[16] Perry, P. and Wolff, S. (1974) New Giemsa Method for the Differential Staining of Sister Chromatids. Nature, 251, 156-158. http://dx.doi.org/10.1038/251156a0

[17] Krishna, G., Xu, J., Nath, J., Petersen, M. and Ong, T. (1985) In Vivo Cytogenic Studies on Mice Exposed to Ethylene Dibromide. Mutation Research/Genetic Toxicology, 158, 81-87. http://dx.doi.org/10.1016/0165-1218(85)90101-6

[18] Pérez-Herrera, N., Ceballos-Quintal, J.M. and Pinto-Escalante, D. (1996) Prevalencia de intercambio de cromátides hermanas en una población libre de exposición a agentes clastogénicos. Revista Biomédica, 10, 71-76.

[19] Ostrosky-Wegman, P. and Gonsebatt, M.E. (1997) Biomarcadores moleculares en la determinación de efectos xenobióticos. Gaceta Médica de México, 133, 93-96.

[20] Ocampo, A.P., Hoyos, L.S. and Carvajal, S. (2001) Medición del daño genético inducido por el Basuco en linfocitos humanos empleando la prueba de micronúcleos con citocalasina b. Acta Biológica Colombiana, 6, 59-66.

[21] Poblete, M.T. (2002) Marcadores de utilidad en cáncer mamario. Cuadernos de Cirugía, 15, 74-79. http://dx.doi.org/10.4206/cuad.cir.2001.v15n1-14

[22] Figueroa, L., Bargallo, E., Castorena, G. and Valancia, S. (2009) Cáncer de mama familiar, BRCA1 positivo. Revista Chilena de Cirugía, 61, 547-551. http://dx.doi.org/10.4067/S0718-40262009000600010

[23] Hick, A.S., Paczkowski, M.G., Gadano, B.A. and Carballo, M.A. (2007) Biomarcadores de genotoxicidad en individuos expuestos a arsénico. Latin American Journal of Pharmacy, 26, 691-699.

[24] Gallardo, J., Rubio, B., Baraja, O., González, C. and Cunill, E. (2001) Quimioterapia en Cáncer de mama ¿Qué drogas? ¿Cuánto? ¿Cuántas? Revista Hospital Clínico Universidad de Chile, 12, 134-146. 
Scientific Research Publishing (SCIRP) is one of the largest Open Access journal publishers. It is currently publishing more than 200 open access, online, peer-reviewed journals covering a wide range of academic disciplines. SCIRP serves the worldwide academic communities and contributes to the progress and application of science with its publication.

Other selected journals from SCIRP are listed as below. Submit your manuscript to us via either submit@scirp.org or Online Submission Portal.
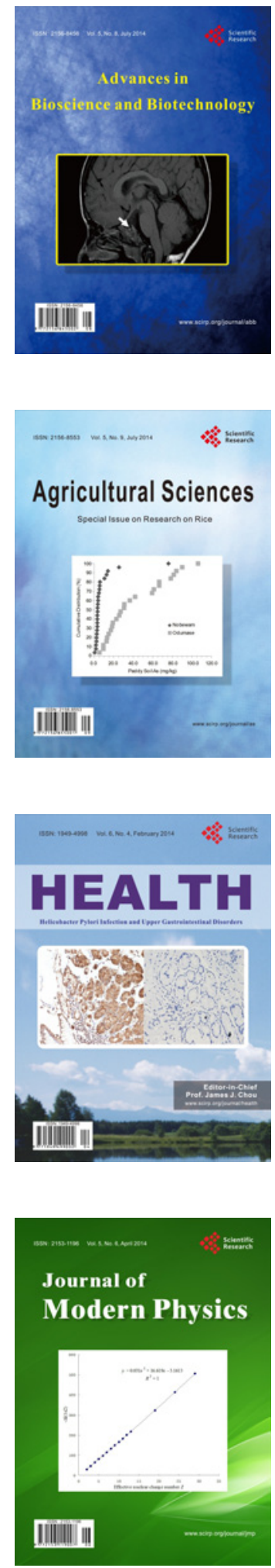
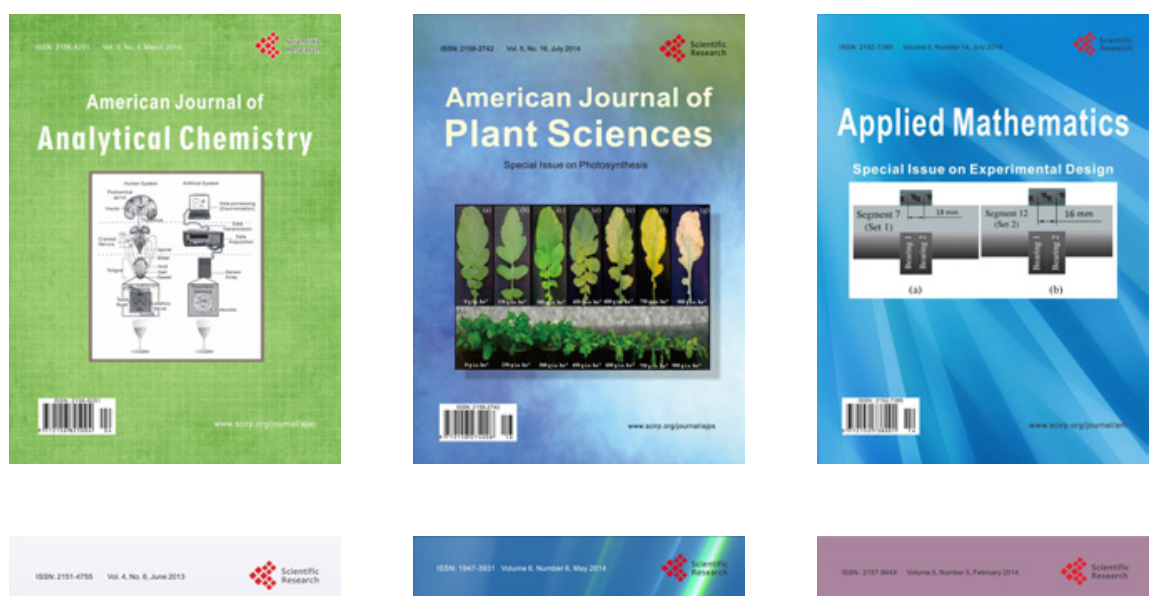

Creative Education
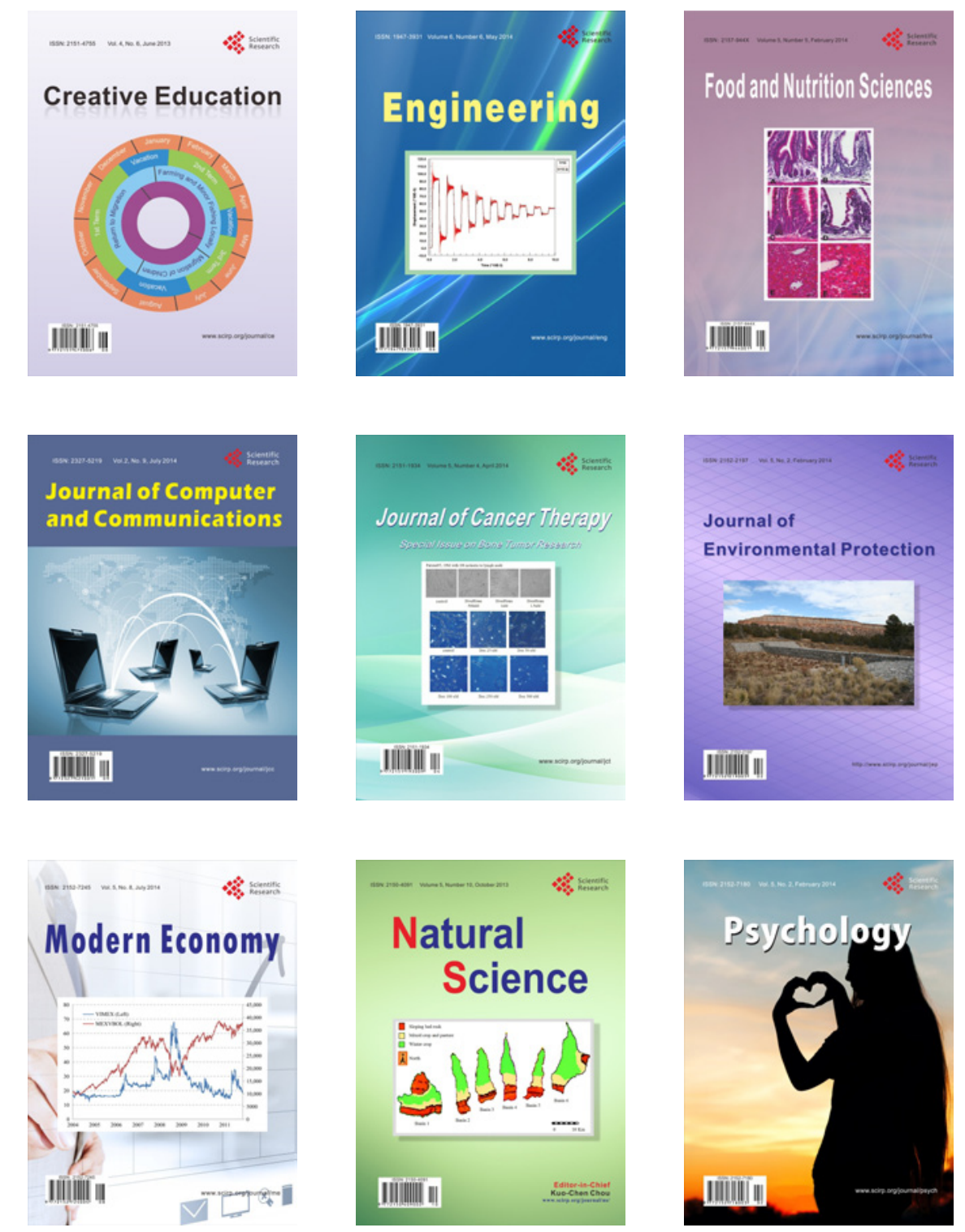